Article

\title{
S-Acyl-2-Thioethyl: A Convenient Base-Labile Protecting Group for the Synthesis of siRNAs Containing $5^{\prime}$-Vinylphosphonate
}

\author{
Mehran Nikan, Wenyu Li, Garth A. Kinberger, Punit P. Seth, Eric E. Swayze and \\ Thazha P. Prakash *
}

Ionis Pharmaceuticals Inc., 2855 Gazelle Ct, Carlsbad, CA 92008, USA; mnikan@ionisph.com (M.N.); lwyt99@yahoo.com (W.L.); gkinberg@yahoo.com (G.A.K.); pseth@ionisph.com (P.P.S.); eswayze@ionisph.com (E.E.S.)

* Correspondence: tprakash@ionisph.com; Tel.: +1-760-603-2590

Academic Editors: Shigeki Sasaki and Marcel Hollenstein

Received: 21 December 2018; Accepted: 7 January 2019; Published: 9 January 2019

\begin{abstract}
We recently reported that $(E)-5^{\prime}$-vinylphosphonate $\left(5^{\prime}-\mathrm{VP}\right)$ is a metabolically-stable phosphate mimic for siRNA and demonstrated that $5^{\prime}$-VP improves the potency of the fully modified siRNAs in vivo. Here, we report an alternative synthesis of $5^{\prime}$-VP modified guide strand using $S$-pivaloyl-2-thioethyl ( $t$ Bu-SATE) protecting group. The $t$ Bu-SATE group is readily removed during the final cleavage of the oligonucleotide from the solid support and providing a more convenient route for the synthesis of siRNA guide strand carrying a $5^{\prime}$-vinylphosphonate.
\end{abstract}

Keywords: SATE; siRNA; vinylphosphonate

\section{Introduction}

RNA interference (RNAi) is a powerful tool for gene regulation and modulation of disease causing genes [1,2]. Potential of this technology for developing drugs to treat unmet medical needs is proven with recent approval of ONPATTRO ${ }^{\mathrm{TM}}$ (patisiran) for the treatment of hereditary transthyretin-mediated amyloidosis. There are several siRNA drugs progressing in the clinic with positive clinical results [3-5]. It is necessary to develop stability enhanced siRNA to capture the broader potential of the RNAi therapeutics.

Judicious placement of nucleic acid modifications in each strand led to the development of siRNA derivatives with both improved potency and stability [6-8]. The 5'-phosphate of siRNA guide strand makes critical H-bonding interactions within the Mid domain of the Argonaute-2 (Ago2) that ensures proper positioning and accurate slicing of target mRNA [9-11]. The 5'-phosphorylated guide strands are prone to enzymatic cleavage of the terminal phosphate due to the action of phosphatases in vivo [12]. We have previously reported the synthesis of a metabolically stable (E)-5'-vinylphosphonate as a phosphate mimic for guide strand (Figure 1, $5^{\prime}-\mathrm{VP}$ ) and its incorporation into the single and double-stranded siRNAs [13]. These modified strands are stable to phosphatase-mediated cleavage and are 5-10 times more potent than the corresponding siRNAs containing a natural phosphate in mice [14]. The X-ray crystal structure of the siRNAs containing 5'-VP in complex with human Ago2 revealed that it maintains the key interactions with Ago2 proteins like the 5'-phosphate moiety [15]. While our reported synthetic strategy was successful in yielding the desired product, further protecting group optimization was required for convenient synthesis of $5^{\prime}$-VP siRNAs. 

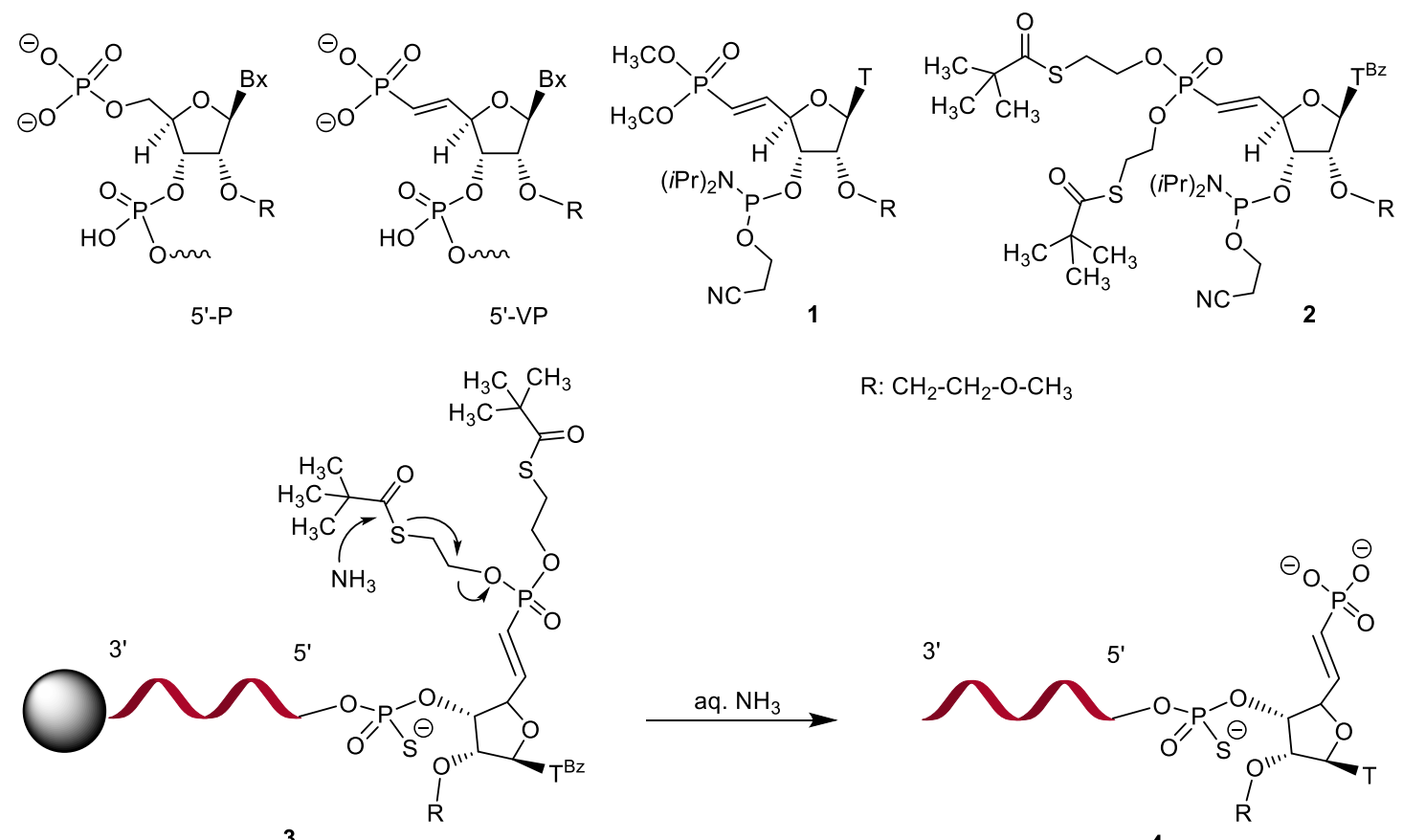

R: $\mathrm{CH}_{2}-\mathrm{CH}_{2}-\mathrm{O}-\mathrm{CH}_{3}$

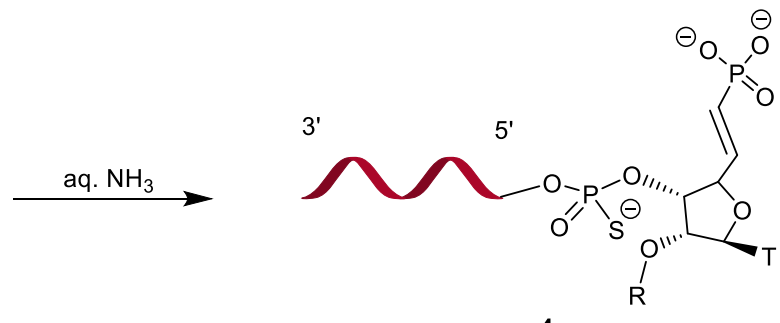

4

Figure 1. Structure of $5^{\prime}$-phosphate $\left(5^{\prime}-\mathrm{P}\right),(E)-5^{\prime}$-vinylphosphonate $\left(5^{\prime}-\mathrm{VP}\right), 5^{\prime}$-deoxy-(E)-5'-vinyl phosphonate-2'-O-(2-methoxyethyl)-thymidine- $3^{\prime}$-phosphoramidite bearing methyl 1 and $t$ Bu-SATE 2 phosphonate esters; proposed mechanism ( 3 and 4 ) for aqueous ammonia assisted deprotection of $t \mathrm{Bu}-\mathrm{SATE}$ protecting group.

In our previous synthesis of $5^{\prime}$-VP siRNA and ss-siRNA, we utilized $5^{\prime}$-deoxy-(E)-5'-vinyl (dimethylphosphonate)-2'-O-(2-methoxyethyl)-thymidine-3'-phosphoramidite 1 (Figure 1) for incorporation of VP modification at $5^{\prime}$-end of guide strand. The synthesis of siRNAs and ss-siRNA were achieved by standard automated DNA synthesis using the phosphoramidite 1 (Figure 1) and the phosphonate moiety was protected as dimethyl esters [13]. While the methyl groups provided the desired stability during synthesis, their removal required an additional iodotrimethylsilane (TMSI) treatment prior to deprotection of oligonucleotides from the solid support [7]. TMSI mediated deprotection of the methyl groups required strictly anhydrous conditions. Thus, this protecting-group strategy is not amenable to automation and scale-up when a large oligonucleotide library synthesis is intended. These considerations prompted us to explore an alternate synthetic strategy where the phosphonate protecting group can be readily removed under basic conditions. One such approach using pivaloyloxymethyl protecting group was reported very recently [16].

The tert-S-pivaloyl-2-thioethyl ( $t$ Bu-SATE) group has been successfully utilized in the synthesis of nucleotide prodrugs and charge neutral oligonucleotides [17-20]. We envisage that tBu-SATE could be a suitable protecting group for installing the vinylphosphonate during solid phase oligonucleotide synthesis and could be conveniently removed using standard aqueous ammonia deprotection as shown in Figure 1 (3 and 4). Herein, we report the synthesis of the $5^{\prime}$-deoxy-(E)-5'-vinyl-bis(tBu-SATE)phosphonate)-2'-O-(2-methoxyethyl)-thymidine-3'-phosphoramidite 2 (Figure 1) and its application to synthesize $5^{\prime}$-VP modified guide strand of siRNA. Using phosphoramidite 2 the synthesis of $5^{\prime}$-VP modified siRNA was accomplished using conventional oligonucleotide synthesis methods and $t \mathrm{Bu}$-SATE protecting group was efficiently removed during aqueous ammonia treatment (3 and 4, Figure 1). 


\section{Results and Discussion}

\subsection{Synthesis of}

5'-deoxy-(E)-5'-vinyl-bis(tBu-SATE)phosphonate)-2'-O-(2-methoxyethyl)-thymidine-3'-phosphoramidite 2

Overall strategy for the synthesis of bis(tBu-SATE) protected phosphoramidite 2 is described in Scheme 1. Synthesis started from a known nucleoside 5, which was synthesized using a reported procedure [13]. First $N^{3}$ position of the thymine of compound 5 was protected as the benzoyl amide by treatment with benzoyl chloride $(\mathrm{BzCl})$ in presence of $N, N$-diisopropylethylamine (DIEA) in dichloromethane to afford 6 (79\%). The methyl protecting groups of 6 were then removed quantitatively by treatment with TMSI in dichloromethane to afford 7 . The compound 7 was first converted to vinylphosphonic dichloride derivative 8 by reacting with oxalyl chloride in dichloromethane containing 2,6-di-tert-butyl-4-methylpyridine and catalytic amount of DMF. The vinylphosphonic dichloride derivative 8 was then reacted with $t$ Bu-SATE alcohol 9 [20] to afforded bis( $t$ Bu-SATE) derivative $\mathbf{1 0}$ in 30\% yield over two steps. Compound $\mathbf{1 0}$ was then treated with triethylamine trihydrofluoride (TREAT-HF) to yield $\mathbf{1 1}(68 \%)$. Finally, 11 was reacted with 2-cyanoethyl- $N, N, N^{\prime}, N^{\prime}$-tetraisoproylphosphorodiamidite (Phosphitylating reagent) in the presence of $1 H$-tetrazole and $N$-methylimidazole in DMF to yield compound $2(82 \%)$.

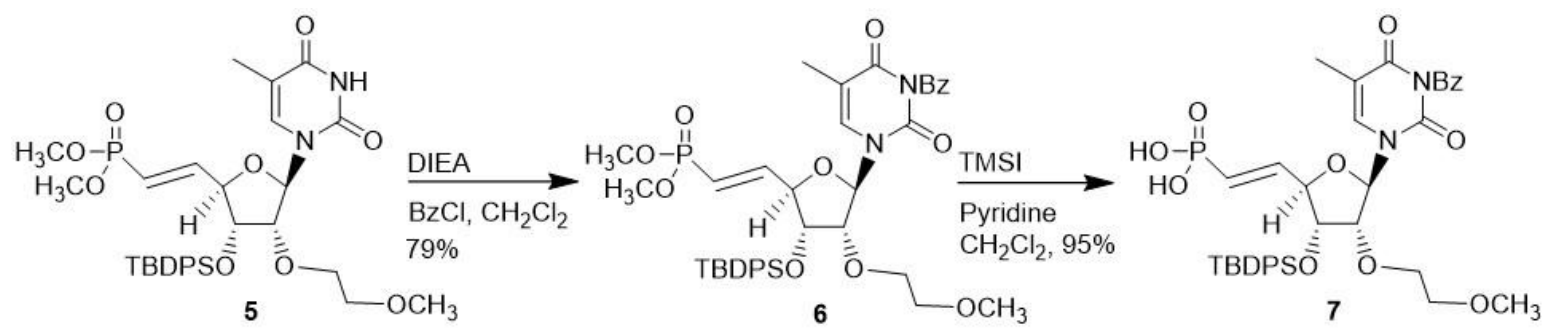

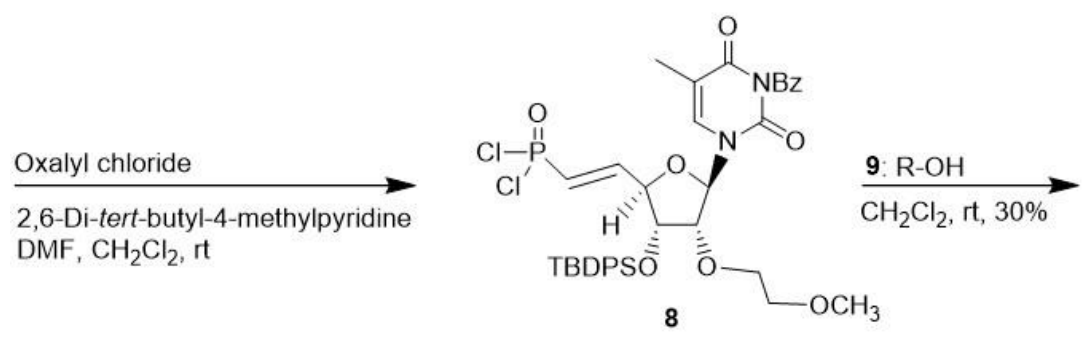

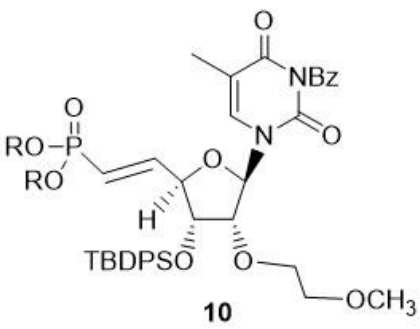

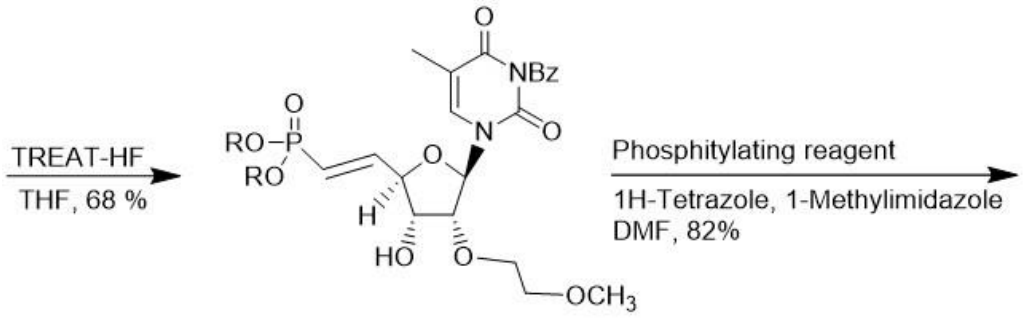
11

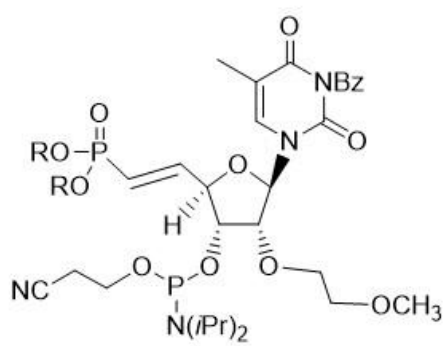

2<smiles>[Z10]CCSC(=O)C(C)(C)C</smiles>

Scheme 1. Synthesis of $5^{\prime}$-deoxy-(E)-5'-vinyl-bis(tBu-SATE)phosphonate)-2'-O-(2-methoxyethyl)thymidine- $3^{\prime}$-phosphoramidite 2 . 
(A)

SiRNA 12/13

Passenger Strand 12: 5' $\mathrm{A}_{\mathrm{S}} \mathrm{C}_{\mathrm{S}} \mathrm{C}_{0} \mathrm{U}_{0} \mathrm{G}_{0} \mathrm{~A}_{0} \mathrm{U}_{0} \mathrm{C}_{0} \mathrm{~A}_{0} \mathrm{U}_{0} \mathrm{U}_{0} \mathrm{~A}_{0} \mathrm{U}_{0} \mathrm{~A}_{0} G_{0} \mathrm{~A}_{0} \mathrm{U}_{5} \mathrm{~A}_{\mathrm{S}} \mathrm{A}-3^{\prime}$

Guide Strand 13: 3'- $A_{s} A_{s} \cup_{s} G_{s} G_{s} A_{s} C_{s} \cup_{o} A_{s} G_{o} \cup_{s} A_{o} A_{s} \cup_{o} A_{s} \cup_{o} C_{s} \cup_{o} A_{s} \cup T-5$ '

$T=$ 2'$^{\prime}-\mathrm{O}-\mathrm{MOE}-$ thymidine-(E)-5'-vinylphosphonate; o: $\mathrm{X}=\mathrm{O} ; \mathrm{s}: \mathrm{X}=\mathrm{S} ; \mathrm{Bx}: \mathrm{A}, \mathrm{G}, \mathrm{C}, \mathrm{U}$<smiles>[X]P(=O)(OC)O[C@H]1C(Br)O[C@@H](COC)[C@H]1OC</smiles><smiles>[X]P(=O)(O)OC1C(COC)OC(Br)C1F</smiles>

2'-O-Me RNA

2'-F RNA

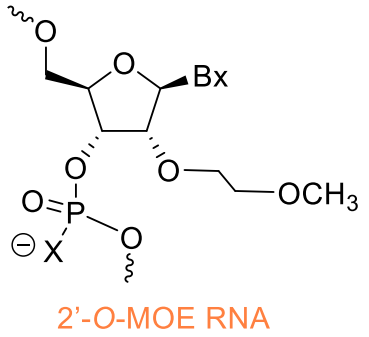

(B)

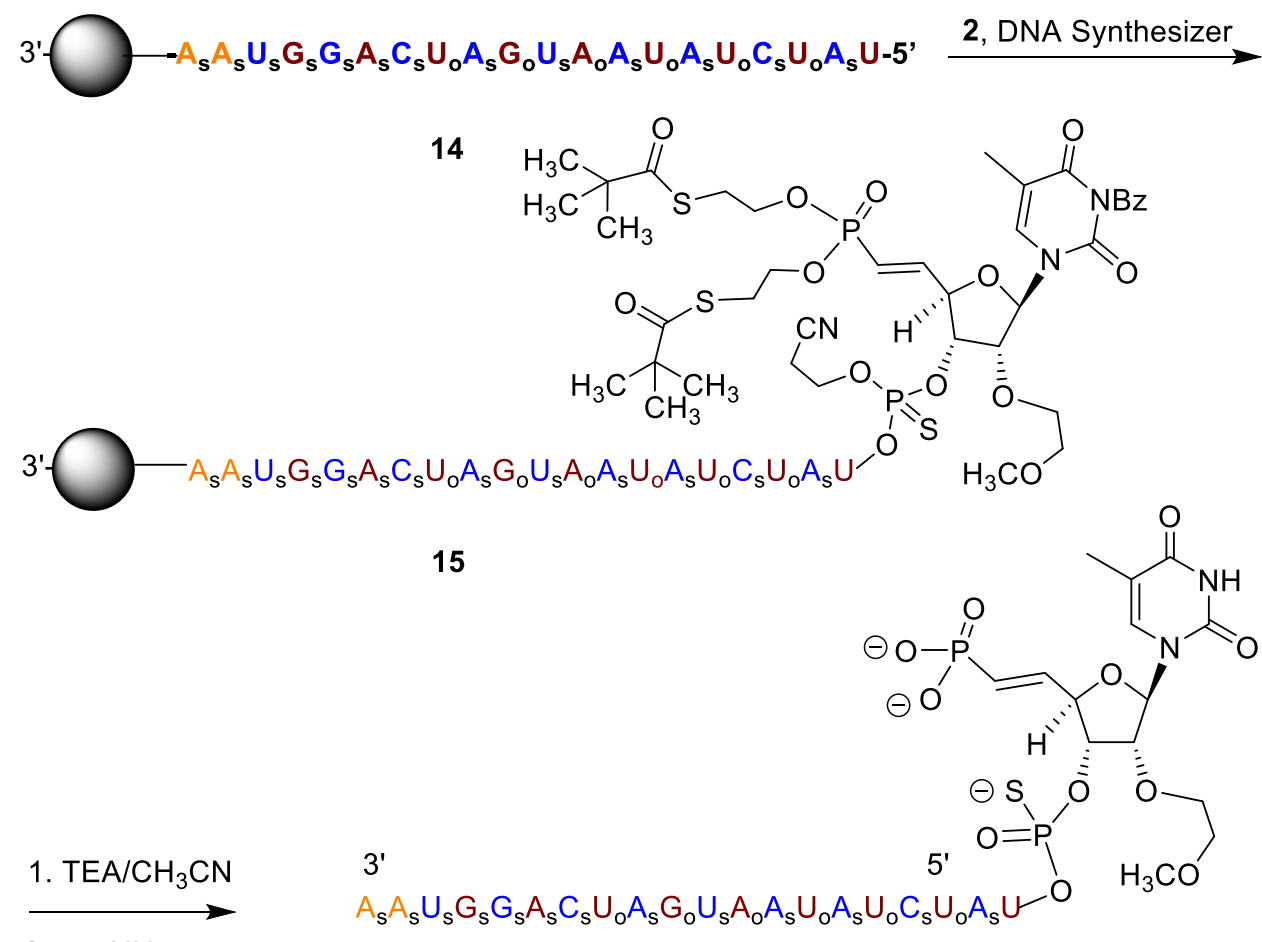

2. aq. $\mathrm{NH}_{3}$

13

Figure 2. (A) siRNA 12/13 targeting murine phosphate and tensin homolog (PTEN) containing an alternating 2'-F/2'-O-Me motif with a (E)-5'-VP-2'-O-MOE T; (B) Solid-phase synthesis of siRNA guide strand 13 using bis( $t$ Bu-SATE)-protected phosphoramidite 2.

\subsection{Synthesis of Oligonucleotides Using}

5'-deoxy-(E)-5'-vinyl-bis(tBu-SATE)phosphonate)-2'-O-(2-methoxyethyl)-thymidine-3'-phosphoramidite 2

We synthesized a guide strand of previously described modified siRNA 12/13 (Figure 2) targeting murine PTEN containing an alternating $2^{\prime}-\mathrm{F} / 2^{\prime}-\mathrm{O}-\mathrm{Me}$ motif with a $(E)-5^{\prime}-\mathrm{VP}-2^{\prime}-\mathrm{O}-\mathrm{MOE}$ $\mathrm{T}$ [12]. We first synthesized precursor guide strand 14 lacking $5^{\prime}$-VP on a DNA synthesizer using UnyLinker solid support and 2'-F, 2'-O-Me and 2'-O-MOE modified nucleoside phosphoramidites (Figure 2) [8]. For incorporation of (E)-5'-VP-2'-O-MOE T residue we used phosphoramidite 2 containing bis(tBu-SATE)-protected $5^{\prime}$-VP (Figure 2) [13]. After the synthesis of guide strand 15 was completed the solid support was treated with $50 \%$ triethylamine in acetonitrile containing $1 \mathrm{M}$ 2-mercaptoethanol for $30 \mathrm{~min}$ to remove the cyanoethyl groups from the phosphate and phosphorothioate linkages. The oligonucleotide was then cleaved and deprotected using aqueous ammonia (28-30 wt\%) containing $1 \mathrm{M} 2$-mercaptoethanol at $55{ }^{\circ} \mathrm{C}$ for $6 \mathrm{~h}$ or at $25^{\circ} \mathrm{C}$ for $24 \mathrm{~h}$ to yield 
guide strand 13 (Figure 2). 2-Mercaptoethanol was used to scavenge the acrylonitrile and episulfide (Figure 1) generated during the deprotection of cyanoethyl groups and from $t$ Bu-SATE protecting groups respectively. The guide strand $\mathbf{1 3}$ was then purified by high pressure liquid chromatography (HPLC) and characterized by LCMS analysis (Table 1).

Table 1. Synthesis scale, deprotection condition and analytical data of guide strand $\mathbf{1 3}$ synthesized using $t \mathrm{Bu}-\mathrm{SATE}$ vs. methyl protecting groups.

\begin{tabular}{ccccccc}
\hline Comp. & $\begin{array}{c}\text { Protecting } \\
\text { Group }\end{array}$ & $\begin{array}{c}\text { Deprotection } \\
\text { Temperature }\end{array}$ & $\begin{array}{c}\text { Mol. Wt. } \\
\text { Calculated }\end{array}$ & $\begin{array}{c}\text { Mol. Wt. } \\
\text { Found }\end{array}$ & Scale $\boldsymbol{\mu m o l}$ & \%UV Purity \\
\hline $\mathbf{1 3}$ & SATE & $55^{\circ} \mathrm{C}$ & 7300.4 & 7299.3 & 2 & 99.3 \\
$\mathbf{1 3}$ & SATE & $25^{\circ} \mathrm{C}$ & 7300.4 & 7299.1 & 2 & 98.6 \\
$\mathbf{1 3}$ & $\mathrm{Me}$ & $55^{\circ} \mathrm{C}$ & 7300.4 & 7299.1 & 2 & 99.1 \\
\hline
\end{tabular}

For comparison we also synthesized guide strand 13 using phosphoramidite 1 containing $5^{\prime}$-VP methyl esters [13]. Synthesis was accomplished on a DNA synthesizer according to the reported procedure [13]. Conventional deprotection condition (aqueous ammonia at $55{ }^{\circ} \mathrm{C}$ ) was not able to hydrolyze both methyl esters of the $5^{\prime}$-VP moiety. A post-synthetic treatment of solid support bearing guide strand $\mathbf{1 3}$ with a solution of TMSI in dichloromethane was needed to completely remove methyl groups. In contrast, for the guide strand 13 containing $5^{\prime}$-VP bis( $t$ Bu-SATE) esters, conventional aq. ammonia treatment completely removed $t$ Bu-SATE esters from the $5^{\prime}$-VP moiety.

Thus, $t \mathrm{Bu}$-SATE approach simplifies the synthesis of $5^{\prime}$-VP modified oligonucleotides and eliminated the need for moisture sensitive and inconvenient TMSI treatment. The overall isolated yield obtained for the synthesis of guide strand $\mathbf{1 3}$ using phosphoramidites containing methyl or $t$ Bu-SATE esters were similar. Our results suggest that $t$ Bu-SATE is a convenient protecting group for the solid-phase synthesis of $5^{\prime}-\mathrm{VP}$ modified oligonucleotides.

\section{Materials and Methods}

General

All reactions were carried out under an argon atmosphere using anhydrous solvents unless otherwise stated. Anhydrous solvents and reagents were purchased from commercial sources and used without further purification. Chromatography was performed on Biotage SP1 system equipped with UV detector and SNAP prepacked columns (Biotage LLC, Charlotte, NC, USA). Analytical thin-layer chromatography (TLC) was performed using silica gel $60 \mathrm{~F}_{254}$ (Merck KGaA, Darmstadt, Germany) using UV lamp (UVP, Upland, CA, USA) a visualizing agent and developed by a solution of p-anisaldehyde (6 mL), $\mathrm{H}_{2} \mathrm{SO}_{4}(8.3 \mathrm{~mL}), \mathrm{CH}_{3} \mathrm{COOH}(2.5 \mathrm{~mL})$ in $\mathrm{C}_{2} \mathrm{H}_{5} \mathrm{OH}(227 \mathrm{~mL})$ followed by charring. ${ }^{1} \mathrm{H}-\mathrm{NMR}$ spectra were recorded on a Bruker $300 \mathrm{MHz}$ instrument (Billerica, MA, USA) using residual solvent as reference. ${ }^{31} \mathrm{P}-\mathrm{NMR}$ spectra are not calibrated and $\delta$ is reported relative to $85 \%$ phosphoric acid. Yields refer to chromatographically isolated yields. Compound $\mathbf{1}$ was synthesized using the reported procedure [13].

Compound 2: To a solution of $11(0.51 \mathrm{~g}, 0.651 \mathrm{mmol})$ in DMF $(2.0 \mathrm{~mL})$ were added $1 H$-tetrazole ( $36 \mathrm{mg}, 0.521 \mathrm{mmol}), 1$-methylimidazole $(13 \mathrm{mg}, 0.163 \mathrm{mmol})$, followed by 2-cyanoethyl $\mathrm{N}, \mathrm{N}, \mathrm{N}^{\prime}, \mathrm{N}^{\prime}$-tetraisopropylphosphordiamidite $(0.31 \mathrm{~mL}, 0.977 \mathrm{mmol})$. The reaction was complete after $2 \mathrm{~h}$ as determined by TLC using 70\% ethyl acetate/hexanes as the eluent. The reaction mixture was diluted with saturated $\mathrm{NaHCO}_{3}$ and partitioned against ethyl acetate. The aqueous layer was then extracted with ethyl acetate. The ethyl acetate layers were combined, dried over $\mathrm{Na}_{2} \mathrm{SO}_{4}$, filtered and concentrated. The resulting crude compound was purified by silica gel column chromatography and eluted with $70 \%$ ethyl acetate/hexanes to yield 2 (0.5 g, 82\%). ${ }^{31} \mathrm{P}-\mathrm{NMR}\left(121 \mathrm{MHz}, \mathrm{CDCl}_{3}\right): \delta 150.54-150.09(\mathrm{~d}, 1 \mathrm{P})$, 18.07-17.32 (d, 1P); LR MS (ESI) calcd for $\mathrm{C}_{44} \mathrm{H}_{66} \mathrm{~N}_{4} \mathrm{O}_{13} \mathrm{P}_{2} \mathrm{~S}_{2}[\mathrm{M}-\mathrm{H}]^{-} m / z=983.3$, found 982.1. 
Compound 6: To a solution of $5(5.0 \mathrm{~g}, 7.72 \mathrm{mmol})$ in $\mathrm{CH}_{2} \mathrm{Cl}_{2}(35 \mathrm{~mL})$ were added DIEA (2.69 mL, $15.43 \mathrm{mmol})$ and benzoylchloride $(1.12 \mathrm{~mL}, 9.65 \mathrm{mmol})$ and stirred at room temperature overnight. Reaction mixture was concentrated by rotary evaporation under reduced pressure and the residue was purified by silica gel column chromatography by a gradient of hexanes:ethyl acetate (1:1) to ethyl acetate to afford $6(4.56 \mathrm{~g}, 79 \%) .{ }^{1} \mathrm{H}-\mathrm{NMR}\left(300 \mathrm{MHz}, \mathrm{CDCl}_{3}\right): \delta 7.83-7.95(\mathrm{~m}, 2 \mathrm{H}), 7.58-7.77(\mathrm{~m}, 4 \mathrm{H})$, 7.32-7.55 (m, 9H), $6.94(\mathrm{~s}, 1 \mathrm{H}), 6.56-6.77(\mathrm{~m}, 1 \mathrm{H}), 5.79-5.98(\mathrm{~m}, 2 \mathrm{H}), 4.65(\mathrm{t}, 1 \mathrm{H}), 3.98(\mathrm{t}, 1 \mathrm{H}), 3.67-3.71$ $(\mathrm{d}, 6 \mathrm{H}), 3.32-3.61(\mathrm{~m}, 5 \mathrm{H}), 3.29(\mathrm{~s}, 3 \mathrm{H}), 1.9(\mathrm{~s}, 3 \mathrm{H}), 1.01(\mathrm{~s}, 9 \mathrm{H}) ;{ }^{31} \mathrm{P}-\mathrm{NMR}\left(121 \mathrm{MHz}, \mathrm{CDCl}_{3}\right): \delta 19.44$; LR MS (ESI) calcd for $\mathrm{C}_{39} \mathrm{H}_{47} \mathrm{~N}_{2} \mathrm{O}_{10} \mathrm{PSi}[\mathrm{M}-\mathrm{H}]^{-} \mathrm{m} / z=761.2$, found 761.3.

Compound 7: To a solution of $6(3.82 \mathrm{~g}, 5.01 \mathrm{mmol})$ in $\mathrm{CH}_{2} \mathrm{Cl}_{2}(15 \mathrm{~mL})$ were added pyridine $(1.67 \mathrm{~mL}, 20.0 \mathrm{mmol})$ and TMSI $(1.28 \mathrm{~mL}, 12.53 \mathrm{mmol})$ and stirred at room temperature. Reaction was completed after $30 \mathrm{~min}$ as determined by LC-MS (6130 Quadruple LC/MS, Agilent Technologies, Santa Clara, CA, USA). The reaction mixture was concentrated under reduced pressure and the residue was suspended in ethyl acetate and filtered. The filtrate was washed with $0.1 \mathrm{~N} \mathrm{HCl}$, dried over $\mathrm{MgSO}_{4}$, filtered and concentrated to afford $7(3.5 \mathrm{~g}, 95 \%) .{ }^{1} \mathrm{H}-\mathrm{NMR}\left(300 \mathrm{MHz}, \mathrm{CDCl}_{3}\right): \delta 7.81-7.94(\mathrm{~m}, 2 \mathrm{H})$, 7.56-7.77 (m, 4H), 7.30-7.53 (m, 9H), $6.97(\mathrm{~s}, 1 \mathrm{H}), 6.49-6.72(\mathrm{~m}, 1 \mathrm{H}), 5.89-6.01(\mathrm{~m}, 2 \mathrm{H}), 4.62(\mathrm{t}, 1 \mathrm{H})$, $4.01(\mathrm{t}, 1 \mathrm{H}), 3.32-3.61(\mathrm{~m}, 5 \mathrm{H}), 3.28(\mathrm{~s}, 3 \mathrm{H}), 1.84(\mathrm{~s}, 3 \mathrm{H}), 1.09(\mathrm{~s}, 9 \mathrm{H}) ;{ }^{31} \mathrm{P}-\mathrm{NMR}\left(121 \mathrm{MHz}, \mathrm{CDCl}_{3}\right): \delta 10.2$; LR MS (ESI) calcd for $\mathrm{C}_{37} \mathrm{H}_{43} \mathrm{~N}_{2} \mathrm{O}_{10} \mathrm{PSi}[\mathrm{M}+\mathrm{H}]^{+} \mathrm{m} / z=735.2$, found 735.1.

Compound 10: To a solution of $7(2.5 \mathrm{~g}$ 3. $41 \mathrm{mmol})$ in $\mathrm{CH}_{2} \mathrm{Cl}_{2}(8.4 \mathrm{~mL})$ were added 2,6-di-tert-butyl-4-methylpyridine (4.20 g, $20.48 \mathrm{mmol})$, oxalyl chloride $(0.78 \mathrm{~g}, 6.15 \mathrm{mmol})$ and DMF (catalytic). The reaction mixture was stirred at room temperature for $1 \mathrm{~h}$ to afford 8 in situ. The reaction mixture was concentrated under reduced pressure and residue dissolved in $\mathrm{CH}_{2} \mathrm{Cl}_{2}$. tBu-SATE alcohol 9 (3.32 g, $20.48 \mathrm{mmol})$ was added and the reaction mixture was stirred at room temperature overnight. The reaction mixture was concentrated under reduced pressure and the residue was partitioned between ethyl acetate and $\mathrm{H}_{2} \mathrm{O}$. The organic layer was separated, dried $\left(\mathrm{MgSO}_{4}\right)$, filtered and concentrated. The crude product was purified by silica gel column chromatography (ethyl acetate: hexanes; 1:1) to yield 10 (1.05 g, 31\%). ${ }^{1} \mathrm{H}-\mathrm{NMR}\left(300 \mathrm{MHz}, \mathrm{CDCl}_{3}\right): \delta 7.84-7.95(\mathrm{~m}, 2 \mathrm{H})$, 7.59-7.77 (m, 4H), 7.33-7.55 (m, 9H), $6.96(\mathrm{~s}, 1 \mathrm{H}), 6.57-6.78(\mathrm{~m}, 1 \mathrm{H}), 5.80-6.01(\mathrm{~m}, 2 \mathrm{H}), 4.65(\mathrm{t}, 1 \mathrm{H})$, 3.93-4.16 (m, 5H), 3.31-3.65 (m, 5H), $3.29(\mathrm{~s}, 3 \mathrm{H}), 3.10(\mathrm{~m}, 4 \mathrm{H}), 1.90(\mathrm{~s}, 3 \mathrm{H}), 1.23(\mathrm{~s}, 18 \mathrm{H}), 1.10(\mathrm{~s}, 9 \mathrm{H})$; ${ }^{31} \mathrm{P}-\mathrm{NMR}\left(121 \mathrm{MHz}, \mathrm{CDCl}_{3}\right.$ ): $\delta$ 17.21; LR MS (ESI) calcd for $\mathrm{C}_{51} \mathrm{H}_{67} \mathrm{~N}_{2} \mathrm{O}_{12} \mathrm{PS}_{2} \mathrm{Si}[\mathrm{M}-\mathrm{H}]^{-} m / z=1021.3$, found 1021.4 .

Compound 11: To a solution of $10(1.0 \mathrm{~g}, 0.98 \mathrm{mmol})$ in THF $(3.0 \mathrm{~mL})$ was added TREAT-HF $(1.2 \mathrm{~mL}, 7.34 \mathrm{mmol})$ and stirred at room temperature overnight. The reaction mixture was concentrated under reduced pressure and the residue obtained was purified by silica gel column chromatography using a gradient of ethyl acetate to $50 \%$ acetone $/ \mathrm{CH}_{2} \mathrm{Cl}_{2}$ to afford $11(0.52 \mathrm{~g}, 68 \%)$. ${ }^{1} \mathrm{H}-\mathrm{NMR}(300 \mathrm{MHz}$, DMSO-d $\left.d_{6}\right): \delta 7.92-8.04(\mathrm{~m}, 2 \mathrm{H}), 7.75-7.86(\mathrm{~m}, 1 \mathrm{H}), 7.70(\mathrm{~s}, 1 \mathrm{H}), 7.56-7.66(\mathrm{~m}, 2 \mathrm{H}), 6.73-6.95(\mathrm{~m}, 1 \mathrm{H})$, 6.00-6.20 (m, 1H), $5.85(\mathrm{~d}, 1 \mathrm{H}), 5.45(\mathrm{~d}, 1 \mathrm{H}), 4.40(\mathrm{t}, 1 \mathrm{H}), 4.12-4.26(\mathrm{~m}, 2 \mathrm{H}), 3.93-4.10(\mathrm{~m}, 4 \mathrm{H}), 3.60-3.82$ $(\mathrm{m}, 2 \mathrm{H}), 3.48(\mathrm{~m}, 2 \mathrm{H}), 3.24(\mathrm{~s}, 3 \mathrm{H}), 3.11(\mathrm{~m}, 4 \mathrm{H}), 1.89(\mathrm{~s}, 3 \mathrm{H}), 1.19(\mathrm{~s}, 18 \mathrm{H}) ;{ }^{31} \mathrm{P}-\mathrm{NMR}(121 \mathrm{MHz}$, DMSO- $d_{6}$ ): $\delta$ 22.24; LR MS (ESI) calcd for $\mathrm{C}_{35} \mathrm{H}_{49} \mathrm{~N}_{2} \mathrm{O}_{12} \mathrm{PS}_{2}[\mathrm{M}-\mathrm{H}]^{-} m / z=783.2$, found 783.3.

Compound 13: The synthesis of modified oligonucleotides was performed on an $\mathrm{ABI}$ 394 synthesizer (Biolytic Lab Performance Inc., Fremont, CA, USA) on a $2 \mu$ mol scale. A $0.1 \mathrm{M}$ solution of 2'-F, 2'-O-Me, and 2'-O-MOE, modified nucleoside phosphoramidites in anhydrous acetonitrile $\left(\mathrm{CH}_{3} \mathrm{CN}\right)$ and were used for the synthesis. Phosphoramidite 2 was dissolved in $30 \%$ dichloromethane in anhydrous $\mathrm{CH}_{3} \mathrm{CN}(0.1 \mathrm{M})$ and used for the oligonucleotide synthesis. The modified oligonucleotides were synthesized on VIMAD UnyLinker ${ }^{\mathrm{TM}}$ (AM Chemicals, Oceanside, CA, USA) solid support. Dichloroacetic acid (6\%) in toluene was used as detritylating reagent. 4,5-Dicyanoimidazole in the presence of $\mathrm{N}$-methylimidazole in $\mathrm{CH}_{3} \mathrm{CN}$ was used as activator during the coupling step. During the coupling step, nine equivalents of phosphoramidite solutions were delivered and the coupling was carry out for $10 \mathrm{~min}$. Phosphorothioate linkages were introduced by sulfurization with a $0.05 \mathrm{M}$ solution of DDTT (3-((dimethylamino-methylidene)amino)-3H-1,2,4-dithiazole-3-thione) in 1:1 pyridine $/ \mathrm{CH}_{3} \mathrm{CN}$ for a contact time of $3 \mathrm{~min}$. Phosphate diester linkages were incorporated 
via oxidation of phosphite triesters using a solution of tert-butyl hydroperoxide $/ \mathrm{CH}_{3} \mathrm{CN} /$ water (10:87:3) for a contact time of $12 \mathrm{~min}$. All other steps in the protocol supplied by the manufacturer were used without modification. After the desired sequence was assembled, the solid-support bound oligonucleotide was washed with 1:1 TEA/ $\mathrm{CH}_{3} \mathrm{CN}$ for $30 \mathrm{~min}$. The solid-support bound oligonucleotide was suspended in aqueous ammonia (28-30 wt \%) containing 1M 2-mercaptoethanol (used $1 \mathrm{~mL} / \mu \mathrm{mol}$ of solid support) and either heated at $55^{\circ} \mathrm{C}(13$, Table 1$)$ for $6 \mathrm{~h}$ or kept at room temperature for $24 \mathrm{~h}(\mathbf{1 3}$, Table 1$)$ to complete cleavage from support. The unbound oligonucleotide was then filtered and the support was rinsed and filtered with water:ethanol (1:1) followed by water. The filtrate was combined and concentrated to dryness. The residue obtained was purified by HPLC

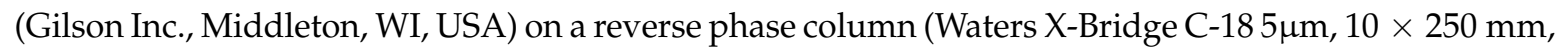
$\mathrm{A}=5 \mathrm{mM}$ tributylammonium acetate in $5 \%$ aqueous $\mathrm{CH}_{3} \mathrm{CN}, \mathrm{B}=\mathrm{CH}_{3} \mathrm{CN}, 0$ to $90 \% \mathrm{~B}$ in $80 \mathrm{~min}$,

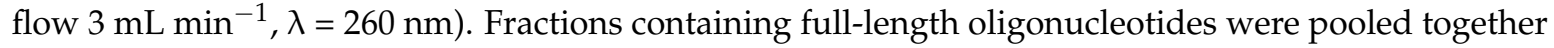
(assessed by LC/MS analysis $>95 \%$ ) and the tributylammonium counter ion was exchanged to sodium by HPLC on a strong anion exchange column (GE Healthcare Bioscience, Pittsburgh, PA, USA) Source $30 \mathrm{Q}, 30 \mu \mathrm{m}, 2.54 \times 8 \mathrm{~cm}, \mathrm{~A}=100 \mathrm{mM}$ ammonium acetate in $30 \%$ aqueous $\mathrm{CH}_{3} \mathrm{CN}, \mathrm{B}=1.5 \mathrm{M} \mathrm{NaBr}$ in $\mathrm{A}, 0-40 \%$ of $\mathrm{B}$ in $60 \mathrm{~min}$, flow $14 \mathrm{~mL} \mathrm{~min}^{-1}$ ). The residue was desalted by HPLC on reverse phase column to yield the oligonucleotide in an isolated yield of $15-20 \%$ based on solid-support loading. The oligonucleotides were characterized by ion-pair-HPLC-MS analysis with Agilent 1100 MSD system (Agilent Technologies, Santa Clara, CA, USA).

\section{Conclusions}

In this study, we designed and synthesized $5^{\prime}$-deoxy-(E)-5'-vinyl-phosphonate)-2'-O-(2methoxyethyl)-thymidine- $3^{\prime}$-phosphoramidite with a base-labile $t$ Bu-SATE protected vinylphosphonate in good yield. To examine the compatibility of the $t$ Bu-SATE-protecting group under solid-phase oligonucleotide synthesis conditions, we synthesized a guide strand of fully modified siRNA containing $(E)$-5'-vinylphosphonate using this phosphoramidite. The $t$ Bu-SATE-protected phosphoramidite was successfully incorporated at the $5^{\prime}$-terminus of a $2^{\prime}-\mathrm{F} / 2^{\prime}-\mathrm{O}-\mathrm{Me}$ guide strand of siRNA using solid-phase DNA synthesis reagents and methods. Moreover, the $t \mathrm{Bu}-\mathrm{SATE}$ group was conveniently removed under aqueous ammonia mediated deprotection conditions. The yield and purity of resulting oligonucleotides were identical to the one obtained using previously reported phosphoramidite containing vinylphosphonate methyl esters [13]. The strategy described in this report simplify the synthesis and deprotection of the siRNAs containing a metabolically stable $(E)$-5'-vinylphosphonate and eliminates the need for any additional steps or reagents.

Author Contributions: Conceptualization, T.P.P. and E.E.S.; methodology, T.P.P., P.P.S., G.A.K., M.N., W.L.; writing, review and editing, T.P.P., P.P.S., M.N.

Funding: Funding for open access charge: Ionis Pharmaceuticals

Acknowledgments: We thank Walt F. Lima and Stanley T. Crooke for supporting this work

Conflicts of Interest: The authors declare no conflict of interest. All authors are employees or former employees of Ionis Pharmaceuticals Inc.

\section{References}

1. Elbashir, S.M.; Harborth, J.; Lendeckel, W.; Yalcin, A.; Weber, K.; Tuschl, T. Duplexes of 21-nucleotide RNAs mediate RNA interference in cultured mammalian cells. Nature 2001, 411, 494-498. [CrossRef] [PubMed]

2. Fire, A.; Xu, S.; Montgomery, M.K.; Kostas, S.A.; Driver, S.E.; Mello, C.C. Potent and specific genetic interference by double-stranded RNA in Caenorhabditis elegans. Nature 1998, 391, 806-811. [CrossRef] [PubMed]

3. Coelho, T.; Adams, D.; Silva, A.; Lozeron, P.; Hawkins, P.N.; Mant, T.; Perez, J.; Chiesa, J.; Warrington, S.; Tranter, E.; et al. Safety and Efficacy of RNAi Therapy for Transthyretin Amyloidosis. New England J. Med. 2013, 369, 819-829. [CrossRef] [PubMed] 
4. Sehgal, A.; Barros, S.; Ivanciu, L.; Cooley, B.; Qin, J.; Racie, T.; Hettinger, J.; Carioto, M.; Jiang, Y.; Brodsky, J.; et al. An RNAi therapeutic targeting antithrombin to rebalance the coagulation system and promote hemostasis in hemophilia. Nat. Med. 2015, 21, 492-497. [CrossRef] [PubMed]

5. Shen, X.; Corey, D.R. Chemistry, mechanism and clinical status of antisense oligonucleotides and duplex RNAs. Nucleic Acids Res. 2018, 46, 1584-1600. [CrossRef] [PubMed]

6. Deleavey, G.F.; Damha, M.J. Designing Chemically Modified Oligonucleotides for Targeted Gene Silencing. Chem. Biol. (Oxford, U.K.) 2012, 19, 937-954. [CrossRef] [PubMed]

7. Prakash, T.P.; Allerson, C.R.; Dande, P.; Vickers, T.A.; Sioufi, N.; Jarres, R.; Baker, B.F.; Swayze, E.E.; Griffey, R.H.; Bhat, B. Positional Effect of Chemical Modifications on Short Interference RNA Activity in Mammalian Cells. J. Med. Chem. 2005, 48, 4247-4253. [CrossRef] [PubMed]

8. Allerson, C.R.; Sioufi, N.; Jarres, R.; Prakash, T.P.; Naik, N.; Berdeja, A.; Wanders, L.; Griffey, R.H.; Swayze, E.E.; Bhat, B. Fully 2'-modified oligonucleotide duplexes with improved in vitro potency and stability compared to unmodified small interfering RNA. J. Med. Chem 2005, 48, 901-904. [CrossRef] [PubMed]

9. Wang, Y.; Juranek, S.; Li, H.; Sheng, G.; Tuschl, T.; Patel, D.J. Structure of an argonaute silencing complex with a seed-containing guide DNA and target RNA duplex. Nature 2008, 456, 921-926. [CrossRef] [PubMed]

10. Nakanishi, K.; Weinberg, D.E.; Bartel, D.P.; Patel, D.J. Structure of yeast Argonaute with guide RNA. Nature 2012, 486, 368-374. [CrossRef] [PubMed]

11. Schirle, N.T.; MacRae, I.J. The crystal structure of human Argonaute2. Science 2012, 336, 1037-1040. [CrossRef] [PubMed]

12. Prakash, T.P.; Kinberger, G.A.; Murray, H.M.; Chappell, A.; Riney, S.; Graham, M.J.; Lima, W.F.; Swayze, E.E.; Seth, P.P. Synergistic effect of phosphorothioate, 5'-vinylphosphonate and GalNAc modifications for enhancing activity of synthetic siRNA. Bioorg. Med. Chem. Lett. 2016, 26, 2817-2820. [CrossRef] [PubMed]

13. Prakash, T.P.; Lima, W.F.; Murray, H.M.; Li, W.; Kinberger, G.A.; Chappell, A.E.; Gaus, H.; Seth, P.P.; Bhat, B.; Crooke, S.T.; et al. Identification of metabolically stable $5^{\prime}$-phosphate analogs that support single-stranded siRNA activity. Nucleic Acids Res. 2015, 43, 2993-3011. [CrossRef] [PubMed]

14. Lima, W.F.; Prakash, T.P.; Murray, H.M.; Kinberger, G.A.; Li, W.; Chappell, A.E.; Li, C.S.; Murray, S.F.; Gaus, H.; Seth, P.P.; et al. Single-stranded siRNAs activate RNAi in animals. Cell 2012, 150, 883-894. [CrossRef] [PubMed]

15. Schirle, N.T.; Kinberger, G.A.; Murray, H.F.; Lima, W.F.; Prakash, T.P.; MacRae, I.J. Structural Analysis of Human Argonaute-2 Bound to a Modified siRNA Guide. J. Am. Chem Soc. 2016, 138, 8694-8697. [CrossRef] [PubMed]

16. Parmar, R.G.; Brown, C.R.; Matsuda, S.; Willoughby, J.L.S.; Theile, C.S.; Charissé, K.; Foster, D.J.; Zlatev, I.; Jadhav, V.; Maier, M.A.; et al. Facile Synthesis, Geometry, and 2'-Substituent-Dependent in vivo Activity of 5'-(E)- and 5'-(Z)-Vinylphosphonate-Modified siRNA Conjugates. J. Med. Chem. 2018, 61, 734-744. [CrossRef] [PubMed]

17. Peyrottes, S.; Egron, D.; Lefebvre, I.; Gosselin, G.; Imbach, J.L.; Perigaud, C. SATE pronucleotide approaches: An overview. Mini Rev. Med. Chem. 2004, 4, 395-408. [CrossRef] [PubMed]

18. Meade, B.R.; Gogoi, K.; Hamil, A.S.; Palm-Apergi, C.; van den Berg, A.; Hagopian, J.C.; Springer, A.D.; Eguchi, A.; Kacsinta, A.D.; Dowdy, C.F.; et al. Efficient delivery of RNAi prodrugs containing reversible charge-neutralizing phosphotriester backbone modifications. Nat. Biotechnol 2014, 32, 1256-1261. [CrossRef] [PubMed]

19. Prakash, T.P.; Prhavc, M.; Eldrup, A.B.; Cook, P.D.; Carroll, S.S.; Olsen, D.B.; Stahlhut, M.W.; Tomassini, J.E.; MacCoss, M.; Galloway, S.M.; et al. Synthesis and Evaluation of S-Acyl-2-thioethyl Esters of Modified Nucleoside 5'-Monophosphates as Inhibitors of Hepatitis C Virus RNA Replication. J. Medi. Chem. 2005, 48, 1199-1210. [CrossRef] [PubMed]

20. Lefebvre, I.; Perigaud, C.; Pompon, A.; Aubertin, A.M.; Girardet, J.L.; Kirn, A.; Gosselin, G.; Imbach, J.L. Mononucleoside phosphotriester derivatives with S-acyl-2-thioethyl bioreversible phosphate-protecting groups: intracellular delivery of $3^{\prime}$-azido-2', $3^{\prime}$-dideoxythymidine $5^{\prime}$-monophosphate. J. Med. Chem 1995, 38, 3941-3950. [CrossRef] [PubMed]

Sample Availability: Samples of the compounds 1, 5 and 13 are available from the authors. 